\title{
ANALISIS KEPUASAN MASYARAKAT TERHADAP PELAYANAN PUBLIK BERDASARKAN INDEKS KEPUASAN MASYARAKAT (IKM) KANTOR KECAMATAN SAWAN KABUPATEN BULELENG
}

\author{
Luh Dea Damayanti ${ }^{1}$, Kadek Rai Suwena², lyus Akhmad Haris ${ }^{3}$ \\ Jurusan Pendidikan Ekonomi, Fakultas Ekonomi \\ Universitas Pendidikan Ganesha Singaraja, \\ Indonesia \\ e-mail: luhdeadamayanti12@yahoo.co.id ${ }^{1}$, \\ kadek_suwena@yahoo.co.id ${ }^{2}$, iyus.haris@gmail.com ${ }^{3}$
}

\begin{abstract}
Abstrak
Penelitian ini bertujuan untuk mengetahui persepsi dan kepuasan masyarakat terhadap pelayanan Kantor Kecamatan Sawan Kabupaten Buleleng diukur berdasarkan kepuasan masyarakat menggunakan Indeks Kepuasan Masyarakat (IKM) ditinjau dari pelayanan administratif. Penelitian ini merupakan penelitian deskriptif dengan menggunakan analisis Indeks Kepuasan Masyarakat berdasarkan Keputusan Menteri Pendayagunaan Aparatur Negara Nomor 25 Tahun 2004. Penelitian ini dilaksanakan di Kantor Kecamatan Sawan dengan jumlah responden 150 orang menggunakan teknik sampling non probability sampling dengan jenis accidental sampling. Data yang dikumpulkan, dilakukan dengan metode kuisioner atau angket. Hasil penelitian menunjukkan persepsi masyarakat terhadap pelayanan Kantor Kecamatan Sawan diukur berdasarkan kepuasan masyarakat menggunakan IKM masyarakat dari keseluruhan indikator pelayanan sudah sesuai dengan harapan masyarakat namun dari segi fasilitas untuk pengaduan masyarakat seperti kotak saran belum ada. Kepuasan masyarakat terhadap pelayanan Kantor Kecamatan Sawan diukur berdasarkan kepuasan masyarakat menggunakan IKM secara total dari 14 indikator pelayanan pada rentang nilai IKM 2,51-3,25 dengan nilai konversi IKM pada rentang 62,51-81,25 yang berada pada kategori mutu pelayanan dan kinerja pelayanan baik. Hal ini mengindikasikan bahwa masyarakat merasa puas tenhadap pelayanan yang diberikan dengan adanya mutu pelayanan dan kinerja pelayanan yang baik.
\end{abstract}

Kata kunci: kepuasan, pelayanan, persepsi

\section{Abstract}

This study aims to determine the perception and satisfaction of society to the service of Sawan District Office of Buleleng Regency measured based on the satisfaction of the community using Public Satisfaction Index (IKM) in terms of administrative services. This research is descriptive research using Satisfaction Index analysis based on Decree of Minister of Administrative Reform of State Number 25 Year 2004. This research was conducted at Sawan District Office with 150 respondents using non probability sampling sampling technique with accidental sampling type. Data collected, conducted by questionnaire or questionnaire method. The result of the research shows that people's perception on service of Sawan sub-district office is measured based on community satisfaction using IKM community from all service indicator is in accordance with society expectation but in terms of facility for public complaint like suggestion box not yet exist. Satisfaction of society to service of Sub-District of Sawan is measured based on community satisfaction using IKM in total from 14 service indicator in SMI value range 2,51-3,25 with IKM conversion value in the range 62,51-81,25 which is in service quality category and Good service performance. This indicates that the community is satisfied with the services provided by the quality of service and good service performance.

Keywords: satisfaction, service, perception

\section{PENDAHULUAN}

Setiap manusia membutuhkan

pelayanan. Manusia membutuhkan

pelayanan untuk memenuhi berbagai macam kebutuhan yang tidak dapat dipenuhi sendiri, bahkan secara ekstrim dapat dikatakan bahwa pelayanan tidak 
dapat dipisahkan dengan kehidupan manusia. Oleh karena itu pelayanan yang diberikan kepada masyarakat menuntut kualitas tertentu. Pelayanan yang diselenggarakan pengelola melalui aparatnya, walaupun tidak bertujuan mencari keuntungan namun tetap harus mengutamakan kualitas layanan yang sesuai dengan tuntunan, harapan dan kebutuhan masyarakat yang dilayani (Sinambela, 2006).

Pelayanan adalah kegiatan pemberian jasa dari sutau pihak kepada pihak lainnya. Pelayanan yang baik adalah pelayanan yang dilakukan secara ramah tamah, adil cepat dan dengan etika yang baik sehingga memenuhi kebutuhan dan kepuasan bagi yang menerimanya (Hasibuan, 2005:152). Kasmir (2005:15), mengatakan bahwa "Pelayanan diberikan sebagai tindakan atau perbuatan seseorang atau organisasi untuk memberikan kepuasan kepada pelanggan atau nasabah". Tindakan tersebut dapat dilakukan melalui cara langsung berhadapan dengan pelanggan atau menempatkan sesuatu dimana pelanggan atau nasabah sudah tahu tempat atau pelayanan secara tidak langsung. Tindakan tersebut dilakukan guna memenuhi keinginan pelanggan akan sesuatu produk atau jasa yang mereka butuhkan.

Menurut UU RI No. 25 Tahun 2009, pelayanan publik adalah segala kegiatan dalam rangka pemenuhan kebutuhan dasar sesuai dengan hakhak dasar setiap warga Negara dan penduduk atau suatu barang, jasa dan atau pelayanan administrasi yang disediakan oleh penyelenggara pelayanan yang terkait dengan kepentingan publik. Sedangkan berdasarkan kepmenpan No. 63 Tahun 2003, pengertian pelayanan publik adalah segala kegiatan pelayanan yang dilaksanakan oleh penyelenggara pelayanan publik sebagai upaya pemenuhan kebutuhan penerima pelayanan maupun pelaksanaan ketentuan perundang-undangan.

Kepuasan masyarakat terhadap organisasi publik sangat penting karena adanya hubungan kepercayaan masyarakat. Menurut Pasolong (2010:221), "Semakin baik kepemerintahan dan kualitas pelayanan yang diberikan, maka semakin tinggi kepercayaan masyarakat (high trust)". Kepercayaan masyarakat akan semakin tinggi apabila masyarakat menadapatkan pelayanan yang baik dan merasa terpuaskan akan pelayanan tersebut.

Pelayanan publik diberikan kepada masyarakat oleh pemerintah. Terwujudnya pelayanan publik yang berkualitas merupakan salah satu ciri dari pemerintahan yang baik sebagai tujuan dari pendayagunaan aparatur negara. Kepmenpan Nomor 63 tahun 2003 menyebutkan bahwa "Ukuran keberhasilan penyelenggaraan pelayanan ditentukan oleh tingkat kepuasan penerima pelayanan. Kepuasan pelayanan dicapai apabila penerima pelayanan memperoleh pelayanan sesuai dengan yang dibutuhkan dan diharapkan". Oleh karena itu, setiap penyelenggara pelayanan secara berkala melakukan survey indeks kepuasan masyarakat. Kata kepuasan (satisfaction) menurut Tjiptono dan Gregorius Chandra (2005:195) berasal dari bahasa Latin "satis" yang berarti cukup baik, memadai, dan "factio" yang berarti melakukan atau membuat. Kepuasan bisa sebagai "upaya pemenuhan sesuati" atau "membuat sesuatu memadai". Kepuasan (Satisfaction) adalah perasaaan senang atau kecewa seseorang yang muncul setelah membandingkan kinerja (hasil) produk yang dipikirkan terhadap kinerja atau hasil yang diharapkan. Jika kinerja berada di bawah harapan maka pelanggan tidak puas. Jika kinerja memenuhi harapan maka pelanggan puas. Jika kinerja melebihi harapan maka pelanggan amat puas atau senang (Kotler dan Keller, 2007:177). Menurut Lovelock dkk (2010:74) "Kepuasan adalah suatu sikap yang diputuskan berdasarkan pengalaman yang didapatkan. Kepuasan merupakan penilaian mengenai ciri atau 
keistimewaan produk atau jasa, atau produk itu sendiri, yang menyediakan tingkat kesenangan konsumen berkaitan dengan pemenuhan kebutuhan konsumen. Kepuasan konsumen dapat diciptakan melalui kualitas, pelayanan dan nilai. Kunci untuk menghasilkan kesetiaan pelanggan adalah memberikan nilai pelanggan yang tinggi".

Menurut Nasution (2001:45), "Kepuasan pelanggan adalah suatu keadaan di mana kebutuhan, keinginan, dan harapan pelanggan dapat terpenuhi melalui produk yang dikonsumsi". Schnaars dalam Pasolong (2010:221) menyebutkan bahwa terciptanya kepuasan pelanggan dapat memberikan manfaat, diantaranya hubungan antara pelanggan dengan instansi menjadi harmonis, memberikan dasar yang baik bagi pembeli (pemakaian) ulang, terciptanya loyalitas dari pelanggan serta terbentuknya rekomendasi dari mulut ke mulut yang kesemuanya menguntungkan perusahaan sedangkan menurut Saladin (2003:9), pengertian kepuasan pelanggan adalah perasaan senang atau kecewa seseorang yang berasal dari perbandingan antara kesannya terhadap kinerja (hasil) suatu produk dan harapan-harapannya. Menurut Pasolong (2010), kepuasan masyarakat terhadap organisasi publik sangat penting karena adanya hubungan kepercayaan masyarakat. Semakin baik kepemerintahan dan kualitas pelayanan yang diberikan, maka semakin tinggi kepercayaan masyarakat. Kepercayaan masyarakat akan semakin tinggi apabila masyarakat mendapatkan pelayanan yang baik dan merasa terpuaskan akan pelayanan tersebut.

Kepuasan pelaggan dapat diukur menggunakan berbagai metode pengukuran. Menurut Kotler (2002:42), secara sederhana mengemukaan empat metode yang dpaat mengukur kepuasan pelanggan, antara lain sistem keluhan dan saran, survei kepuasan pelanggan, ghost shopping, lost customer analysis. Analisis indeks kepuasan pelanggan merupakan salah satu cara mengetahui tingkat kepuasan pelanggan menggunakan metode survei kepuasan pelanggan.

$$
\text { Menurut Kotler }
$$

pelayanan adalah setiap tindakan atau kegiatan yang dapat ditawarkan oleh suatu pihak lain, yang pada dasarnya tidak berwujud dan tidak mengakibatkan kepemilikan apapun. Kotler juga mengatakan bahwa perilaku tersebut dapat terjadi pada saat, sebelum dan sesudah terjadinya transaksi. Pada umumnya pelayanan yang bertaraf tinggi akan menghasilkan kepuasan yang tinggi serta pembelian ulang yang lebih sering. Sedangkan menurut Gnoroos dalam Ratminto dan Winarsih (2005:2) mendefiniskan pelayanan adalah suatu aktivitas yang bersifat tidak kasat mata (tidak dapat diraba) yang terjadi sebagai akibat adanya interaksi antara konsumen dengan karyawan atau hal-hal lain yang disediakan oleh perusahaan pemberi pelayanan yang dimaksudkan untuk memecahkan permasalahan konsumen pelanggan. Kotler dan Amstrong (2008:292) menyebutkan empat karakteristik dari pelayanan, antara lain intangibility (tidak berwujud), inseparability (tidak dapat dipisahkan), variability (berubah-ubah dan bervariasi), dan perishability (cepat hilang, tidak tahan lama).

Pelayanan publik dibutuhkan masyarakat guna menunjang berbagai kebutuhannya. Karena pada dasarnya masyarakat membutuhkan pelayanan setiap harinya. Menurut Sinambela (2010:128) adalah "Setiap kegiatan yang dilakukan oleh pemerintah terhadap sejumlah manusia yang memilii setiap kegiatan dan menawarkan kepuasn meskipun hasilnya tidak terikat suatu produk secara fisik. Sedangkan definisi pelayanan publik menurut kepmenpan Nomor 63 Tahun 2004 tentang Pedoman Umum Penyelenggaran Pelayanan Publik adalah "Segala kegiatan upaya pemenuhan kebutuhan penerima pelayanan maupun pelaksanaan ketentuan perundangundang". Hakekatnya pelayanan publik 
adalah pemberian pelayanan prima kepada masyarakat yang merupakan perwujudan kewajiban aparatur negara sebagai abdi masyarakat.

Pelayanan publik menjadi ujung tombak interaksi antara masyarakat dan pemerintah. Masyarakat dapat langsung menilai kinerja pemerintah berdasarkan kualitas layanan publik yang diterima, karena kualitas pelayanan publik mejadi kepentingan banyak orang dan dampaknya langsung dapat dirasakan masyarakat dari semua kalangan. Dalam hal ini, keberhasilan pemerintah untuk membangun kinerja pelayanan publik secara profesional, efektif, efesien dan akuntabel akan mengangkat citra positif pemerintah di mata masyarakatnya.

Pemerintah sebagai penyedia layanan publik bertanggung jawab dan terus berupaya untuk memberikan pelayanan yang terbaik kepada masyarakat. Rendahnya mutu pelayanan publik yang diberikan oleh aparatur pemerintah menjadi citra buruk pemerintah di tengah masyarakat. Sebagian masyarakat yang pernah berurusan dengan birokrasi selalu mengeluh dan kecewa terhadap layanan yang diberikan. Ada sebagian masyarakat sampai saat ini masih menganggap rendah terhadap kinerja birokrasi. Akibatnya banyak pengguna layanan atau masyarakat mengambil jalan pintas menggunakan jasa calo untuk mengurus keperluannya yang berhubungan dengan birokrasi pemerintahan.

Pelayanan yang diberikan secara umum belum memuaskan masyarakat. Pelayanan yang diberikan terlalu berbelit-belit dengan berbagai alasan yang kurang dapat diterima oleh masyarakat, sehingga pelayanan yang diberikan cenderung tidak efektif dan efisien. Keadaan yang demikian membuat masyarakat sebagai pengguna layanan publik tidak terpuaskan. Semua itu berakibat masyarakat enggan mengurus segala sesuatu yang berhubungan dengan birokrasi pemerintah secara langsung.
Salah satu kantor pemerintahan yang aktivitasnya memberikan pelayanan publik kepada masyarakat adalah Kantor Kecamatan Sawan, Kabupaten Buleleng. Bentuk layanan yang diberikan berhubungan dengan administrasi kependudukan dan layanan lainnya yang berhubungan dengan pemerintahan di tingkat Kecamatan. Layanan yang diberikan contohnya adalah pembuatan Kartu Keluarga, Kartu Tanda Penduduk, Pengursan Izin Mendirikan Bangunan (IMB), dan fasilitas pelayanan pemerintahan lain bagi masyarakat ataupun bagi pemerintah di tingkat desa.

Berdasarkan pengamatan awal yang telah dilakukan di Kantor Kecamatan Sawan, terdapat beberapa permasalahan yang dijumpai pada bagian pelayanan. Fasilitas pelayanan merupakan salah satu aspek yang memengaruhi kualitas pelayanan yang diberikan. Oleh karena itu, pemenuhan fasilitas pelayanan bagi pelanggan atau masyarakat merupakan salah satu hal yang perlu diperhatikan. Fasilitas pelayanan di Kantor Kecamatan Sawan dianggap masih kurang memadai, seperti tidak adanya kotak saran, tempat duduk pada ruang tunggu yang masih kurang, dan belum tersedia tempat parkir yang aman dan nyaman. $\mathrm{Hal}$ ini dapat mengganggu dan menghambat kelancaran kegiatan pelayanan.

Tujuan utama dari pelayanan publik adalah kepuasan masyarakat. Kepuasan ini dapat terwujud apabila pelayanan yang diberikan sesuai dengan standar pelayanan yang ditetapkan atau lebih baik dari standar pelayanan tersebut. Permasalahan yang masih sering dikeluhkan oleh sebagian masyarakat adalah waktu pelayanan. Waktu pemrosesan layanan kepada masyarakat sekitar dua minggu dianggap masih terlalu lama bagi masyarakat, walaupun lamanya layanan tersebut telah sesuai dengan ketentuan tentang standar waktu pelayanan publik yang ditetapkan dalam undang-undang 
nomor 25 tahun 2009 tentang pelayanan puolik.

Kepuasan pelanggan dapat diukur menggunakan berbagai metode pengukuran salah satunya yaitu survei kepuasan pelanggan. Penilaian yang diberikan masyarakat menentukan ukuran kinerja pelayanan publik. Kegiatan yang dapat dilakukan untuk mengetahui pelayanan publik adalah dengan mengukur tingkat kepuasan masyarakat. Salah satu metode yang digunakan untuk mengetahui kualitas pelayanan suatu organisasi publik adalah dengan menggunakan Indeks Kepuasan Masyarakat (IKM). Ketentuan mengenai Indeks Kepuasan Masyarakat (IKM) tertuang dalam Keputusan Menteri Pendayagunaan Aparatur Negara Nomor KEP/25/M.PAN/2/2004 tanggal 24 Februari 2004 tentang Pedoman Umum Penyusunan Indeks Kepuasan Masyarakat Unit Pelayanan Instansi Pemerintah. Kepuasan masyarakat yang memengaruhi kualitas pelayanan yang diberikan Kantor Kecamatan Sawan menjadi hal menarik untuk dikaji, karena bermaksud untuk mengetahui lebih mendalam mengenai Indeks Kepuasan Masyarakat terhadap pelayanan di Kantor Kecamatan Sawan. Berdasarkan prinsip pelayanan sebagaimana telah ditetapkan dalam kepmenpan Nomor 25 Tahun 2004, terdapat 14 unsur yang relevan, valid dan reliabel sebagai unsur minimal yang harus ada untuk dasar pengukuran indeks kepuasan masyarakat, antara lain prosedur pelayanan, persyaratan pelayanan, kejelasan petugas pelayanan, kedisiplinan petugas pelayanan, tanggungjawab petugas pelayaan, kemampuan petugas pelayanan, kecepatan pelayanan, keadilan mendapatkan pelayanan, kesopanan dan keramahan petugas, kewajaran biaya pelayanan, kepastian biaya pelayanan, kepastian jadwal pelayanan, kenyamanan lingkungan dan keamanan lingkungan. Dalam penelitian ini indikator yang digunakan adalah 14 indikator atau unsur yang tertuang dalam kepmenpan Nomor 25 Tahun
2004 tentang Pedoman Umum Penyusunan Indeks Kepuasan Masyarakat Unit Pelayanan Instansi Pemerintah.

Penelitian ini bertujuan untuk mengetahui persepsi masyarakat dan kepuasan masyarakat terhadap pelayanan Kantor Kecamatan Sawan Kabupaten Buleleng diukur berdasarkan kepuasan masyarakat menggunakan Indeks Kepuasan Masyarakat (IKM) ditinjau dari pelayanan administratif.

\section{METODE}

Desain penelitian yang digunakan dalam penelitian ini adalah penelitian deskriptif. Penelitian ini disebut penelitian deskriptif karena peneliti menghasilkan data berupa gambaran dengan kalimat-kalimat mengeni kepuasan masyarakat terhadap pelayanan di Kantor Kecamatan Sawan. Data yang telah terkumpul dalam bentuk angka-angka kemudian akan dihitung sesuai dengan ketentuan perhitungan IKM. Dari hasil perhitungan Indeks Kepuasan Masyarakat tersebut baru akan dideskripsikan sesuai dengan pengkategorian yang telah ditetapkan berdasarkan kepmenpan Nomor 25 Tahun 2004 dengan 14 indikator yang ditetapkan yaitu prosedur pelayanan, persyaratan pelayanan, kejelasan petugas pelayanan, kedisiplinan petugas pelayanan, tanggungjawab petugas pelayaan, kemampuan petugas pelayanan, kecepatan pelayanan, keadilan mendapatkan pelayanan, kesopanan dan keramahan petugas, kewajaran biaya pelayanan, kepastian biaya pelayanan, kepastian jadwal pelayanan, kenyamanan lingkungan dan keamanan lingkungan.

Teknik pengumpulan data pada penelitian ini menggunakan angket/kuisioner. Populasi dalam penelitian ini adalah seluruh masyarakat yang menjadi pelanggan di Kantor Kecamatan Sawan. Teknik sampling yang digunakan adalah teknik nonprobability sampling, dan teknik pengumpulan data menggunakan accidental sampling yaitu teknik penentuan sampel berdasarkan faktor 
spontanitas, artinya siapa saja yang secara tidak sengaaja bertemu dengan peneliti dan sesuai dengan ciri-cirinya yaitu masyarakat yang menjadi pelanggan pelayanan Kantor Kecamatan Sawan. Sesuai dengan kepmenpan Nomor 25 Tahun 2004 sampel penelitian ditetapkan sejumlah 150 responden sesuai dengan jumlah minimal responden dalam penyusunan indeks kepuasan masyarakat yang dipilih secara tidak sengaja.

Penelitian ini menggunakan teknik analisis data indeks kepuasan masyarakat sesuai dengan kepmenpan Nomor 25 Tahun 2004 pengelolaan data penelitian ditempuh dengan cara sebagai berikut. (1) Editing. Setelah angket diisi oleh reponden dan dikembalikan kepada penulis, segera penulis meneliti kelengkapan dalam pengisian angket sehingga hanya angket yang terisi dengan benar dan sah yang diolah dan digunakan. (2) Tabulasi. Setelah data terkumpul, data tersebut diberikan skor terhadap jawaban 14 indikator Indeks Kepuasan Masyarakat. Penelitian ini menggunakan tabel biasa atau main tabel. (3) Analisis IKM dan Interprestasi. Berdasarkan KEPMENPAN Nomor 25
Tahun 2004, terdapat 14 unsur atau indikator yang dikaji dalam penghitungan IKM. Setiap unsur pelayanan mempunyai penimbang yang sama dengan rumus sebagai berikut.

Bobot nilai rata - rata tertimbang $=$

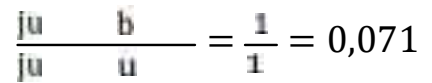

Guna memperoleh nilai IKM digunakan rumus sebagai berikut.

$\mathrm{IKM}=\frac{\text { Total dari Nilai Persepsi Per Unsur }}{\text { Total Unsur yang Terisi }} \times$ Nilai Penimbang

Guna mempermudah interprestasi nilai IKM yang berkisar 25-100, sesuai dengan ketentuan dalam kepmenpan Nomor 25 Tahun 2004, maka hasil penilaian tersebut diatas dikonversikan dengan nilai dasar 25, dengan rumus sebagai berikut.

Nilai Konversi IKM=Nilai IKM Unit Pelayanan x 25

Hasil perhitungan tersebut kemudian dikategorikan sesuai dengan nilai persepsi dan interval nilai IKM seperti pada tabel 1 sebagai berikut.

Tabel 1 Nilai Persepsi, Interval IKM, Interval Konversi IKM

\begin{tabular}{ccccc}
\hline $\begin{array}{c}\text { Nilai } \\
\text { Persepsi }\end{array}$ & $\begin{array}{c}\text { Nilai Interval } \\
\text { IKM }\end{array}$ & $\begin{array}{c}\text { Nilai Interval } \\
\text { Konversi IKM }\end{array}$ & $\begin{array}{c}\text { Mutu } \\
\text { Pelayanan }\end{array}$ & $\begin{array}{c}\text { Kinerja Unit } \\
\text { Pelayanan }\end{array}$ \\
\hline 1 & $1,00-1,75$ & $25,00-43,75$ & D & Tidak Baik \\
2 & $1,76-2,50$ & $43,76-62,50$ & C & Kurang Baik \\
3 & $2,51-3,25$ & $62,51-81,25$ & B & Baik \\
4 & $3,26-4,00$ & $81,26-100,00$ & A & Sangat Baik \\
\hline
\end{tabular}

Guna mendapatkan nilai rata-rata tertimbang per unsur pelayanan, jumlah nilai rata-rata per unsur dikalikan dengan 0,071 sebagai nilai bobot ratarata tertimbang. Sedangkan nilai indeks komposit (gabungan) untuk setiap unit pelayanan, merupakan jumlah nilai ratarata dari setiap unsur pelayanan dikalikan dengan penimbang yang sama, yaitu 0,071 . Hasil dari nilai indeks komposit (gabungan) tersebut merupakan nilai IKM dari Kantor Kecamatan Sawan Kabupaten Buleleng. (4) Penarikan kesimpulan.
Langkah terakhir dalam teknik analisis data adalah menarik kesimpulan dari hasil penelitian dan pemabahasan. Data yang berupa angka dari hasil kuisioner atau angket dijelaskan dalam bentuk kalimat, sehingga diperoleh deskripsi hasil penelitian.

\section{HASIL DAN PEMB AHASAN}

Berdasarkan hasil penelitian yang dilakukan kepada 150 responden mengenai persepsi dan kepuasan masyarakat terhadap pelayanan Kantor Kecamatan Sawan diukur berdasarkan 
kepuasan masyarakat menggunakan Indeks Kepuasan Masyarakat (IKM) ditinjau dari pelayanan administrasi, maka diperoleh hasil Indeks Kepuasan Masyarakat per indikator. Nilai IKM dari indikator pelayanan menunjukkan penilaian masyarakat terhadap indikator pelayanan tersebut. Hasil penelitian dapat dilihat pada tabel 2 di bawah ini.

Tabel 2 Hasil Indeks Kepuasan Masyarakat Per Indikator

\begin{tabular}{|c|c|c|c|c|c|c|}
\hline No. & Indikator Pelayanan & $\begin{array}{l}\text { Jumlah } \\
\text { rata-rata }\end{array}$ & $\begin{array}{l}\text { Nilai } \\
\text { IKM }\end{array}$ & $\begin{array}{c}\text { Nilai } \\
\text { Konversi } \\
\text { IKM }\end{array}$ & $\begin{array}{c}\text { Mutu } \\
\text { Pelayanan }\end{array}$ & Kinerja \\
\hline 1 & Prosedur pelayanan & 482 & 3,21 & 80,25 & B & Baik \\
\hline 2 & Persyaratan pelayanan & 479 & 3,19 & 79,75 & B & Baik \\
\hline 3 & Kejelasan petugas pelayanan & 464 & 3,09 & 77,25 & B & Baik \\
\hline 4 & Kedisiplinan petugas pelayanan & 461,3 & 3,07 & 76,75 & B & Baik \\
\hline 5 & $\begin{array}{l}\text { Tanggung jawab petugas } \\
\text { pelayanan }\end{array}$ & 461 & 3,07 & 76,75 & B & Baik \\
\hline 6 & Kemampuan petugas pelayanan & 455,5 & 3,04 & 76 & B & Baik \\
\hline 7 & Kecepatan pelayanan & 452,5 & 3,02 & 75,50 & B & Baik \\
\hline 8 & $\begin{array}{l}\text { Keadilan mendapatkan } \\
\text { pelayanan }\end{array}$ & 446,5 & 2,98 & 74,50 & B & Baik \\
\hline 9 & $\begin{array}{l}\text { Kesopanan dan keramahan } \\
\text { petugas }\end{array}$ & 460,6 & 3,07 & 76,75 & B & Baik \\
\hline 10 & Kewajaran biaya pelayanan & 457,5 & 3,05 & 76,25 & B & Baik \\
\hline 11 & Kepastian biaya pelayanan & 484,5 & 3,23 & 80,75 & B & Baik \\
\hline 12 & Kepastian jadwal pelayanan & 456 & 3,04 & 76 & B & Baik \\
\hline 13 & Kenyamanan lingkungan & 458 & 3,05 & 76,25 & B & Baik \\
\hline 14 & Keamanan pelayanan & 446,3 & 2,97 & 74,25 & B & Baik \\
\hline
\end{tabular}

Berdasarkan hasil pada tabel 2 persepsi dan kepuasan masyarakat terhadap pelayanan Kantor Kecamatan

Sawan Kabupaten Buleleng diukur berdasarkan kepuasan masyarakat menggunakan Indeks Kepuasan Masyarakat ditinjau dari pelayanan administratif secara total dari 14 indikator pelayanan menunjukkan bahwa persepsi masyarakat sudah sesuai dengan harapan masyarakat selama ini dan masyarakat puas terhadap pelayanan yang diberikan dengan adanya mutu pelayanan dan kinerja pelayanan yang baik.

Berdasarkan hasil penelitian mengenai Indeks Kepuasan Masyarakat Kantor Kecamatan Sawan sesuai dengan ketentuan kepmenpan Nomor 25 Tahun 2004 per indikakor pelayanan berada pada kategori baik. Untuk mengetahui persepsi masyarakat terhadap pelayanan Kantor Kecamatan
Sawan pada setiap indikator akan dibahas sebagai berikut.

(1) Indikator prosedur pelayanan memiliki nilai IKM 3,21 dengan nilai konversi IKM sebesar 80,25 yang berada pada mutu pelayanan dan kinerja pelayanan yang baik. Persepsi masyarakat yang melakukan pelayanan di Kantor Kecamatan Sawan menyatakan bahwa informasi mengenai prosedur pelayanan atau tahapan alur pelayanan di Kantor Kecamatan Sawan mudah untuk didapatkan sehingga masyarakat mudah mengerti tahapan alur dari pelayanan yang diminta. (2) Indikator persyaratan pelayanan memiliki nilai IKM sebesar 3,19 dengan nilai konversi IKM sebesar 79,75 yang berada pada kategori mutu pelayanan dan kinerja pelayanan yang baik. Persepsi masyarakat yang melakukan pelayanan di Kantor Kecamatan Sawan menyatakan bahwa persyaratan pelayanan yang diminta oleh Kantor 
Kecamatan Sawan tidak berbelit-belit sehingga tidak menyusahkan masyarakat yang membutuhkan pelayanan. (3) Indikator kejelasan petugas pelayanan memiliki nilai IKM sebesar 3,09 dengan nilai konversi IKM sebesar 77,25 yang berada pada kategori mutu pelayanan dan kinerja pelayanan yang baik. Persepsi masyarakat yang melakukan pelayanan di Kantor Kecamatan Sawan menyatakan bahwa petugas yang bertugas pada bagian pelayanan selalu ada di loket pelayanan dan petugas yang bertugas sesuai dengan yang terdapat pada jadwal. (4) Indikator kedisiplinan petugas pelayanan memiliki nilai IKM sebesar 3,07 dengan nilai konversi IKM sebesar 76,75 yang berada pada kategori mutu pelayanan dan kinerja pelayanan yang baik. Persepsi masyarakat yang melakukan pelayanan di Kantor Kecamatan Sawan menyatakan bahwa petugas pelayanan sangat disiplin dalam memberikan pelayanan dengan melayani langsung masyarakat yang membutuhkan pelayanan, petugas serius dalam memberikan pelayanan sehingga mengurangi terjadinya kesalahan dan selalu dating tepat waktu sesuai jadwal jam kerja di Kantor Kecamatan Sawan. (5) Indikator tangung jawab petugas pelayanan memiliki nilai IKM sebesar 3,07 dengan nilai konversi IKM sebesar 76,75 yang berada pada kategori mutu pelayanan dan kinerja pelayanan yang baik. Persepsi masyarakat yang melakukan pelayanan di Kantor Kecamatan Sawan menyatakan bahwa petugas pelayanan sangat bertanggung jawab dalam memberikan pelayanan sampai pelayanan yang dibutuhkan masyarakat selesai dengan tuntas. (6) Indikator kemampuan petugas pelayanan memiliki nilai IKM sebesar 3,04 dengan nilai konversi IKM sebesar 76 yang berada pada kategori mutu pelayanan dan kinerja pelayanan yang baik. Persepsi masyarakat yang melakukan pelayanan di Kantor Kecamatan Sawan menyatakan bahwa petugas pelayanan memiliki keahlian dan kecakapan dalam memberikan pelayanan dilihat dari kemampuan penggunaan komputer serta fasilitas lainnya seperti alat rekaman untuk pembuatan E-KTP, kemudian petugas melakukan tindakan cepat dan tepat apabila ada masyarakat yang pada saat melakukan pelayanan E-KTP ada permasalahan seperti tidak terdeteksinya iris mata langsung diberitahu untuk melapor ke pihak kantor catatan sipil agar permasalahan segera ditangani. (7) Indikator kecepatan pelayanan memiliki nilai IKM sebesar 3,02 dengan nilai konversi IKM sebesar 75,50 yang berada pada kategori mutu pelayanan dan kinerja pelayanan yang baik. Persepsi masyarakat yang melakukan pelayanan di Kantor Kecamatan Sawan menyatakan bahwa kecepatan dalam proses pelayanan yang dibutuhkan masyarakat tidak berlangsung lama dan selesai tepat waktu sehingga masyarakat yang melakukan pelayanan tidak sampai menunggu terlalu lama untuk mendapatkan hasil dari pelayanan yang dibutuhkan. (8) Indikator keadilan mendapatkan pelayanan memiliki nilai IKM sebesar 2,98 dengan nilai konversi IKM sebesar 74,50 yang berada pada kategori mutu pelayanan dan kinerja pelayanan yang baik. Persepsi masyarakat yang melakukan pelayanan di Kantor Kecamatan Sawan menyatakan bahwa petugas pelayanan melayani masyarakat sesuai dengan nomor antrian atau yang terlebih dahulu datang untuk melakukan pelayanan tanpa mendahulukan saudara atau kerabat yang kebetulan melakukan pelayanan yang sama dan memberikan informasi yang jelas mengenai pengambilan berkas yang diajukan apabila ada berkas yang harus diselesaikan lebih dari sehari oleh pihak bagian pelayanan. (9) Indikator kesopanan dan keramahan petugas memiliki nilai IKM sebesar 3,07 dengan nilai konversi IKM sebesar 76,75 yang berada pada kategori mutu pelayanan dan kinerja pelayanan yang baik. Persepsi masyarakat yang melakukan pelayanan di Kantor Kecamatan Sawan 
menyatakan bahwa petugas bersikap ramah dan sopan saat masyarakat melakukan pelayanan sehingga masyarakat merasa nyaman dilayani oleh petugas dan petugas juga bersedia menanggapi keluhan masyarakat apabila mengalami permasalahan mengenai surat-surat yang dibutuhkan. (10) Indikator kewajarann biaya pelayanan memiliki nilai IKM sebesar 3,05 dengan nilai konversi IKM sebesar 76,25 yang berada pada kategori mutu pelayanan dan kinerja pelayanan yang baik. Persepsi masyarakat yang melakukan pelayanan di Kantor Kecamatan Sawan menyatakan bahwa besarnya retribusi yang dikeluarkan masyarakat untuk layanan yang ditujukan telah sesuai, wajar dan jelas seperti pungutan uang sukarela saat mengurus surat-surat tertentu namun selama proses penelitian, peneliti tidak melihat adanya pungutan biaya bagi masyarakat yang melakukan pelayanan. (11) Indikator kepastian biaya pelayanan memiliki nilai IKM sebesar 3,23 dengan nilai konversi IKM sebesar 80,75 yang berada pada kategori mutu pelayanan dan kinerja pelayanan yang baik. Persepsi masyarakat yang melakukan pelayanan di Kantor Kecamatan Sawan menyatakan bahwa tidak adanya pungutan biaya tambahan selain retribui resmi dan biaya yang dibayarkan sudah sesuai dengan biaya yang ditetapkan seperti biaya sukarela namun dalam proses penelitian, masyarakat yang melakukan pelayanan sama sekali tidak dikenakan pungutan biaya apapun. (12) Indikator kepastian jadwal pelayanan memiliki nilai IKM sebesar 3,04 dengan nilai konversi IKM sebesar 76 yang berada pada kategori mutu pelayanan dan kinerja pelayanan yang baik. Persepsi masyarakat yang melakukan pelayanan di Kantor Kecamatan Sawan menyatakan bahwa kepastian jadwal pelayanan sudah sesuai dengan jadwal pelayanan yaitu 5 hari kerja kecuali hari libur atau tanggal merah tidak adanya pelayanan. (13) Indikator kenyamanan lingkungan memiliki nilai IKM sebesar 3,05 dengan nilai konversi IKM sebesar
76,25 yang berada pada kategori mutu pelayanan dan kinerja pelayanan yang baik. Persepsi masyarakat yang melakukan pelayanan di Kantor Kecamatan Sawan menyatakan bahwa sarana dan prasarana seperti tempat duduk, taman, penataan ruang pelayanan sudah bersih dan rapi serta memudahkan proses pelayanan sehingga masyarakat merasa nyaman selama melakukan pelayanan. (14) Indikator keamanan pelayanan memiliki nilai IKM sebesar 2,97 dengan nilai konversi IKM sebesar 74,25 yang berada pada kategori mutu pelayanan dan kinerja pelayanan yang baik. Persepsi masyarakat yang melakukan pelayanan di Kantor Kecamatan Sawan menyatakan bahwa keamanan selama mendapatkan pelayanan sudah terjamin dengan adanya beberapa dari pegawai Kantor Camat yang berjaga di dekat area parkir dan lokasi dari Kantor Kecamatan Sawan dekat dengan Kantrol Kepolisian Sektor Sawan hanya saja dari segi fasilitas pengaduan masyarakat seperti kotak saran belum tersedia.

Berdasarkan hasil penelitian mengenai Indeks Kepuasan Masyarakat Kantor Kecamatan Sawan sesuai dengan ketentuan kepmenpan Nomor 25 Tahun 2004 per indikator pelayanan berada pada kategori baik. Untuk mengetahui kepuasan masyarakat terhadap pelayanan Kantor Kecamatan Sawan pada setiap indikator akan dibahas sebagai berikut. (1) Indikator prosedur pelayanan dengan nilai IKM sebesar 3,21 dengan nilai konversi IKM 80,25 yang berada pada kategori mutu pelayanan dan kinerja pelayanan yang baik. Hal ini mengindikasikan bahwa masyarakat merasa puas terhadap pelayanan yang diberikan oleh Kantor Kecamatan Sawan dengan adanya mutu pelayanan dan kinerja pelayanan yang baik. (2) Indikator persyaratan pelayanan dengan nilai IKM sebesar 3,19 dengan nilai konversi IKM 79,75 yang berada pada kategori mutu pelayanan dan kinerja pelayanan yang baik. Hal ini mengindikasikan bahwa masyarakat merasa puas terhadap 
pelayanan yang diberikan oleh Kantor Kecamatan Sawan dengan adanya mutu pelayanan dan kinerja pelayanan yang baik. (3) Indikator kejelasan petugas pelayanan dengan nilai IKM sebesar 3,09 dengan nilai konversi IKM 77,25 yang berada pada kategori mutu pelayanan dan kinerja pelayanan yang baik. Hal ini mengindikasikan bahwa masyarakat merasa puas terhadap pelayanan yang diberikan oleh Kantor Kecamatan Sawan dengan adanya mutu pelayanan dan kinerja pelayanan yang baik. (4) Indikator kedisiplinan petugas pelayanan dengan nilai IKM sebesar 3,07 dengan nilai konversi IKM 76,75 yang berada pada kategori mutu pelayanan dan kinerja pelayanan yang baik. Hal ini mengindikasikan bahwa masyarakat merasa puas terhadap pelayanan yang diberikan oleh Kantor Kecamatan Sawan dengan adanya mutu pelayanan dan kinerja pelayanan yang baik. (5) Indikator tanggung jawab petugas pelayanan dengan nilai IKM sebesar 3,07 dengan nilai konversi IKM 76,75 yang berada pada kategori mutu pelayanan dan kinerja pelayanan yang baik. Hal ini mengindikasikan bahwa masyarakat merasa puas terhadap pelayanan yang diberikan oleh Kantor Kecamatan Sawan dengan adanya mutu pelayanan dan kinerja pelayanan yang baik. (6) Indikator kemampuan petugas pelayanan dengan nilai IKM sebesar 3,04 dengan nilai konversi IKM 76 yang berada pada kategori mutu pelayanan dan kinerja pelayanan yang baik. Hal ini mengindikasikan bahwa masyarakat merasa puas terhadap pelayanan yang diberikan oleh Kantor Kecamatan Sawan dengan adanya mutu pelayanan dan kinerja pelayanan yang baik. (7) Indikator kecepatan pelayanan dengan nilai IKM sebesar 3,02 dengan nilai konversi IKM 75,50 yang berada pada kategori mutu pelayanan dan kinerja pelayanan yang baik. Hal ini mengindikasikan bahwa masyarakat merasa puas terhadap pelayanan yang diberikan oleh Kantor Kecamatan Sawan dengan adanya mutu pelayanan dan kinerja pelayanan yang baik. (8) Indikator keadilan mendapatkan pelayanan dengan nilai IKM sebesar 2,98 dengan nilai konversi IKM 74,50 yang berada pada kategori mutu pelayanan dan kinerja pelayanan yang baik. Hal ini mengindikasikan bahwa masyarakat merasa puas terhadap pelayanan yang diberikan oleh Kantor Kecamatan Sawan dengan adanya mutu pelayanan dan kinerja pelayanan yang baik. (9) Indikator kesopanan dan keramahan petugas dengan nilai IKM sebesar 3,07 dengan nilai konversi IKM 76,75 yang berada pada kategori mutu pelayanan dan kinerja pelayanan yang baik. Hal ini mengindikasikan bahwa masyarakat merasa puas terhadap pelayanan yang diberikan oleh Kantor Kecamatan Sawan dengan adanya mutu pelayanan dan kinerja pelayanan yang baik. (10) Indikator kewajaran biaya pelayanan dengan nilai IKM sebesar 3,05 dengan nilai konversi IKM 76,25 yang berada pada kategori mutu pelayanan dan kinerja pelayanan yang baik. Hal ini mengindikasikan bahwa masyarakat merasa puas terhadap pelayanan yang diberikan oleh Kantor Kecamatan Sawan dengan adanya mutu pelayanan dan kinerja pelayanan yang baik. (11) Indikator kepastian biaya pelayanan dengan nilai IKM sebesar 3,23 dengan nilai konversi IKM 80,75 yang berada pada kategori mutu pelayanan dan kinerja pelayanan yang baik. Hal ini mengindikasikan bahwa masyarakat merasa puas terhadap pelayanan yang diberikan oleh Kantor Kecamatan Sawan dengan adanya mutu pelayanan dan kinerja pelayanan yang baik. (12) Indikator kepastian jadwal pelayanan dengan nilai IKM sebesar 3,04 dengan nilai konversi IKM 76 yang berada pada kategori mutu pelayanan dan kinerja pelayanan yang baik. Hal ini mengindikasikan bahwa masyarakat merasa puas terhadap pelayanan yang diberikan oleh Kantor Kecamatan Sawan dengan adanya mutu pelayanan dan kinerja pelayanan yang baik. (13) Indikator kenyamanan lingkungan dengan nilai IKM sebesar 3,05 dengan nilai konversi IKM 76,25 yang berada pada kategori mutu pelayanan dan 
kinerja pelayanan yang baik. Hal ini mengindikasikan bahwa masyarakat merasa puas terhadap pelayanan yang diberikan oleh Kantor Kecamatan Sawan dengan adanya mutu pelayanan dan kinerja pelayanan yang baik. (14) Indikator keamanan pelayanan dengan nilai IKM sebesar 2,97 dengan nilai konversi IKM 74,25 yang berada pada kategori mutu pelayanan dan kinerja pelayanan yang baik. $\mathrm{Hal}$ ini mengindikasikan bahwa masyarakat merasa puas terhadap pelayanan yang diberikan oleh Kantor Kecamatan Sawan dengan adanya mutu pelayanan dan kinerja pelayanan yang baik.

\section{SIMPULAN DAN SARAN}

Berdasarkan hasil penelitian dan pembahasan yang telah dibuat dapat disimpulkan bahwa persepsi masyarakat terhadap pelayanan Kantor Kecamatan Sawan Kabupaten Buleleng diukur berdasarkan kepuasan masyarakat menggunakan Indeks Kepuasan Masyarakat ditinjau dari pelayanan administratif secara total dari 14 indikator pelayanan berada pada kategori mutu pelayanan dan kinerja pelayanan yang baik. Hal tersebut menggambarkan bahwa persepsi masyarakat dari keseluruhan indikator pelayanan sudah sesuai dengan harapan masyarakat selama ini namun dari segi fasilitas untuk pengaduan masyarakat yang tidak puas atau ada keluhan dalam mendapatkan pelayanan belum ada seperti kotak saran. Sedangkan kepuasan masyarakat terhadap pelayanan Kantor Kecamatan Sawan Kabupaten Buleleng diukur berdasarkan kepuasan masyarakat menggunakan Indeks Kepuasan Masyarakat (IKM) ditinjau dari pelayanan administratif secara total dari 14 indikator pelayanan pada rentang nilai IKM 2,51-3,25 dengan nilai konversi IKM pada rentang 62,51-81,25 yang berada pada kategori mutu pelayanan dan kinerja pelayanan yang baik. Hal tersebut menggambarkan bahwa masyarakat merasa puas terhadap pelayanan yang diberikan dengan adanya mutu pelayanan dan kinerja pelayanan yang baik.

Berdasarkan kesimpulan penelitian, maka peneliti mengemukakan saran kepada Kantor Kecamatan Sawan Kabupaten Buleleng, perlu menyediakan fasilitas pengaduan seperti kotak saran apabila ada masyarakat yang memiliki keluhan terhadap pelayanan yang diberikan tidak memuaskan namun tidak bisa menyampaikan keluhannya secara langsung kepada petugas dapat disampaikan melalui kotak saran tersebut.

\section{DAFTAR PUSTAKA}

Hasibuan, Malayu S P. 2005. Dasardasar Perbankan. Jakarta: Bumi Aksara.

Kasmir. 2005. Etika Customer Service. Jakarta: PT Rajagrafindo Persada.

Keputusan Menteri Pendayagunaan Aparatur Negara Nomor: KEP/25/M.PAN/2/2004 tentang Pedoman Umum Penyusunan Indeks Kepuasan Masyarakat.

Keputusan Menteri Pendayagunaan Aparatur Negara Nomor 63/KEP/M.PAN/7/2003 tentang Pedoman Umum Penyelenggaraan Pelayanan Publik.

Kotler, Philip. 2002. Manajemen Pemasaran di Indonesia: Analisis, Perencanaan, Implementasi dan Pengendalian. Jakarta: Salemba Empat.

Kotler, Philip dan Kevin Lane Keller. 2007. Manajemen Pemasaran Edisi 12. Jakarta: Erlangga.

Kotler, Philip dan Gary Amstrong. 2008. Prinsip-prinsip Pemasaran Edisi

12 Jilid 1. Jakarta: Erlangga. Lovelock, Christopher dkk. 2010. Pemasaran Jasa Perspektif Indonesia Jilid 1 Edisi Ketujuh. Jakarta: Erlangga.

Nasution, M. N. 2001. Manajemen Mutu $\begin{array}{lll}\text { Terpadu } & \text { (Total } & \text { Quality } \\ \text { Management). } & \text { Jakarta: } & \text { Ghalia } \\ \text { Indonesia. } & & \end{array}$ 
Pasolong, Harbani. 2010. Kepemimpinan Birokrasi.

Bandung: CV Alfabeta.

Ratminto dan Atik Septi Winanrsih. 2005. Manajemen Pelayanan.

Yogyakarta: Pustaka Pelajar. Saladin, Djaslim. 2003. Manajemen Strategi \& Kebijakan Perusahaan. Bandung: Linda Karya.

Sinambela, Lijan Poltak dkk. 2006. Reformasi Pelayanan Publik Teori, Kebijakan dan Implementasi. Jakarta: Bumi Aksara.

------. 2010. Reformasi Pelayanan

Publik. Jakarta: Bumi Aksara. Tjiptono, Fandy dan Gregorius Chandra. 2005. Service, Quality \& Satisfaction. Yogyakarta: Andi Offset.

Undang-Undang Nomor 25 tahun 2009 tentang Pelayanan Publik. 